\title{
エピドラスコピーの治療成績と合併症の全国調査結果
}

\begin{tabular}{|c|c|}
\hline & 五十 \\
\hline 玉井謙次*1 & 茂木康一 ${ }^{* 1}$ \\
\hline
\end{tabular}

\begin{abstract}
[要旨］エピドラスコピーを計画した難治性腰下肢痛患者を対象に多施設共同研究を行い，6 月月 後までの有効性と合併症を調査した. その結果, 腰痛, 下肢痛, 下肢しびれ, ADL障害, 旧JOA スコア, 日本語版Roland-Morris Disability Questionnaireのいずれも術前と比較して6 カ月後 まで有意に改善した．エピドラスコピーは, 腰椎の手術歴の有無にかかわらず難治性腰下肢痛に有 効である. 特に, 手術歴がない群は手術歴がある群と比較して有効性が高かった. 術中合併症は頭 痛・頚部痛 37\%, 次いで腰下肢痛 7\%であった. 術後合併症は創部痛4\%, そのほか一過性の下 肢運動障害や膀胱直腸障害, 頭痛, 高血圧, 嘔気の訴えが 1 〜 \%に記録されたが, 重大な合併症 は観察されなかった.

キーワード : エピドラスコピー, 難治性腰下肢痛, 有効性, 合併症
\end{abstract}

はじめに

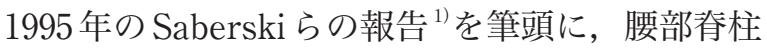
管狭窄症や腰椎椎間板へルニアなどに伴う難治性の 腰下肢痛の軽減にエピドラスコピーが有効であるこ とが示され，わが国では2001年に厚生労㗢省の高 度先進医療に指定され，現在では国内 10 施設にお いて先進医療として施行されている。しかし, 国内 で実際に本治療を受けた患者群における合併症と治 療成績を調査した報告は少なく，今後の国内での普 及のために多施設調査が望まれる。われわれは，統 一調査フォームを用いて国内の複数の施設でエピド ラスコピーの合併症および術後 6 力月間の有効性を 前向きに調査したので，他の報告と比較しながら結 果を紹介する。

${ }^{* 1}$ 自治医科大学麻酔科学・集中治療医学講座

$* 2$ 宇光会村井整形外科医院

\section{I 対象および方法}

2001 年から 2003 年に国内の 15 施設において難治 性の腰下肢痛に対してエピドラスコピーが計画され た症例を前向きに調査した。難治性腰下肢痛の定義 は，従来の保存的治療である消炎鎮痛薬および鎮痛 補助薬の内服, 理学療法, 硬膜外ブロック, 神経根 ブロックなどにより満足な効果が得られないことと した。術後調査に協力が得られない症例，病態を説 明可能な画像所見を認めない症例，下肢症状を伴わ ない腰痛症，股関節・膝関節疾患および梨状筋症候 群，閉塞性動脈硬化症，感染症，内臓疾患，悪性 腫瘍が腰下肢痛の主原因と診断された症例は除外 した。

調査項目および調査方法はエピドラスコピー研究

著者連絡先 村井邦彦

个329-0498 栃木県下野市薬師寺 3311-1

自治医科大学麻酔科学・集中治療医学講座 
表1 エピドラスコピー研究会調査フォーム

患者背景 (年齢, 性別, 罹病期間, 併存症など)

治療成績

日本整形外科学会腰痛疾患治療成績判定基準(旧 JOA スコア $)^{2)}$

日本版 Roland-Morris Disability Questionnair (JRMDQ ${ }^{3}$ VASスコア(腰痛, 下肢痛, 下肢しびれ，ADL 障害の 4項目のそれぞれついて)

副作用・合併症

治療を要したか, 訴えのあった症状

会の主導で統一の調査フォームを用いて行い，術前 および術後 1 力月, 3 力月, および 6 力月に日本整 形外科学会腰痛疾患治療成績判定基準(旧JOA スコ ア $)^{2)}$, 日本版 Roland-Morris Disability Questionnair (JRMDQ)スコア ${ }^{3)}$, visual analogue scale(VAS) ス コア (腰痛，下肢痛，下肢しびれ，ADL障害の4項 目のそれぞれついて)，および治療を要したか訴え のあった副作用・合併症をそれぞれの施設で記録し た(表1).

術後は術前と同様の保存的治療に限り継続が認め られた。内服薬の用量変更を除き，術前に行ってい なかった保存的治療を新たに開始した場合や手術治 療が行われた症例は調査から除外した。

有効性に関する結果の解析は，術前から術後 6 力 月までの全調査項目が満たされた症例を対象とし た。合併症に関する結果の解析は, 術前から術後 6 カ月までの全調査項目が満たされた症例を対象とし たほか, 研究に登録されエピドラスコピーが行われ た全症例を対象とした。術前から術後 6 力月までの 全調査項目が満たされた症例は，さらに腰椎変性疾 患に対する手術歴がある患者群と手術歴のない患者 群に区別して結果を解析した。 VAS 值 $(\mathrm{mm})$ は以下 のVASグレードに変換し分析した。すなわち, VAS 值 0 〜 $20 \mathrm{~mm}$ をVASグレード 1 とし，VAS 值 21 40mm をVASグレード 2, VAS 值 $41 〜 60 \mathrm{~mm}$ をVASグレード3, VAS 值 $61 〜 80 \mathrm{~mm}$ を VASグ レード $4, \mathrm{VAS}$ 值 81 100mm V VASグレード 5 と
した。

統計処理には StatView version 5.0(ヒューリンク ス，東京）を用い，患者背景の解析には対応のない t検定もしくはカイ二乗検定を用いた。 JOA スコア, JRMDQ スコア, VAS グレードの解析には Friedman 検定を用い，有意差が認められた場合にはWilcoxon 順位和検定を用いた。有効性の経時的な変化につい てはMann-Whitney U検定を用いた。 $P<0.05 を$ 有意差ありとした。

\section{II 結 果}

183 症例が研究に登録されたが，3症例で仙骨裂 孔よりビデオガイドカテーテルを挿入できなかっ た。この 3 症例は有効性と合併症の調査から除外さ れた。調査の対象となった 180 症例の背景を表 2 に 示す。

エピドラスコピーが行われた 180 症例のうち，術 後 6 カまでの全調査項目を満たしたのは 84 症例 であった。それ以外の 96 症例は術後の 1 力月， 3 力 月，6力月のいずれかの外来受診が行われなかった か，新たな保存的治療もしくは手術治療が行われた ため，有効性の調査から除外された。明らかに新た な治療が行われて除外されたのは脊髄刺激電極 2 例，エピドラスコピーの再施行 4 例, 頚椎手術 1 例, 腰椎手術 2 例であった。

手術歴のある群と手術歴のない群の間に年齢，性 別，神経根症状と馬尾症状の割合，画像上の腰椎変 性の分類，合併症の点で有意差はなかったが，手術 歴のない群において病悩期間は長く，間欠跛行を合 併する割合が高かった(表2).

有効性に関して，旧JOAスコアとJRMDQスコ アは 6 カ月後まで有意に改善を維持した。旧JOA スコアは手術なし群の方が有意によい結果であった (図1)。また，エピドラスコピー施行前と比較して 腰痛，下肢痛，下肢しびれ，ADL障害のすべての 項目が 6 カ月後まで改善していた．2群間の比較で は下肢痛が 6 カ月後まで，腰痛と下肢しびれが 3 カ 
表2 患者背景

\begin{tabular}{|c|c|c|c|c|c|}
\hline & & $\begin{array}{c}\text { 全症例 } \\
\text { (脱落症例を含む) } \\
n=180\end{array}$ & $\begin{array}{c}6 \text { 力月調査 } \\
\text { 手術歴あり } \\
\mathrm{n}=22\end{array}$ & $\begin{array}{c}6 \text { 力月調査 } \\
\text { 手術歴なし } \\
n=62\end{array}$ & 有意差 \\
\hline \multicolumn{2}{|l|}{ 年齢 } & $60 \pm 16$ & $57 \pm 15$ & $62 \pm 15$ & NS \\
\hline \multicolumn{2}{|c|}{ 病悩期間 (mean \pm SD) } & $48 \pm 59$ & $21 \pm 18$ & $47 \pm 45$ & $\# P=0.00023$ \\
\hline \multicolumn{2}{|c|}{ 過去の腰椎手術回数 $(m e a n \pm S D)$} & - & $1.5 \pm 1.0$ & 0 & \\
\hline & & & 症例数 (\%) & & \\
\hline \multicolumn{6}{|l|}{ 性別 } \\
\hline & 男性 & $104(58)$ & $12(55)$ & $30(48)$ & NS \\
\hline & 女性 & $76(42)$ & $10(45)$ & $32(52)$ & NS \\
\hline \multicolumn{6}{|l|}{ 症状 } \\
\hline & 腰痛 & $163(91)$ & $20(91)$ & $56(90)$ & NS \\
\hline & 下肢痛 & $176(98)$ & $22(100)$ & $61(98)$ & NS \\
\hline & 下肢しびれ感 & $169(94)$ & $21(95)$ & $55(89)$ & NS \\
\hline & 間欠跛行 & $89(49)$ & $10(45)$ & $44(71)$ & $\# P=0.032$ \\
\hline & 膀胱直腸症状 & $12(7)$ & $3(14)$ & $1(2)$ & NS \\
\hline \multicolumn{6}{|l|}{ 病態 } \\
\hline & 神経根症状のみ & $86(48)$ & $12(55)$ & $39(63)$ & NS \\
\hline & 馬尾症状のみ & $12(7)$ & $3(14)$ & $3(5)$ & NS \\
\hline & 混合性 & $82(46)$ & $7(32)$ & $20(32)$ & NS \\
\hline \multicolumn{6}{|l|}{ 診断名 } \\
\hline & 腰部椎間板ヘルニア & $65(36)$ & $3(14)$ & $20(32)$ & NS \\
\hline & 変形性脊椎症 & $70(39)$ & $7(32)$ & $30(48)$ & NS \\
\hline & 変性脊椎すべり症 & $22(12)$ & $2(9)$ & $10(16)$ & NS \\
\hline & 脊椎分離症 & $1(1)$ & $0(0)$ & $1(2)$ & NS \\
\hline & FBSS/MOB & $20(11)$ & $10(45)$ & $0(0)$ & NS \\
\hline & その他 & $2(1)$ & $0(0)$ & $1(2)$ & NS \\
\hline \multicolumn{6}{|l|}{ 併存症 } \\
\hline & 頚椎・胸椎疾患 & $15(8)$ & 2(9) & $2(3)$ & NS \\
\hline & 股関節疾患 $\cdot$ 膝関節疾患 & $5(3)$ & $0(0)$ & $1(2)$ & NS \\
\hline & 糖尿病 & $12(7)$ & $2(9)$ & $0(0)$ & NS \\
\hline & 閉塞性動脈硬化症 & $3(2)$ & $1(5)$ & $0(0)$ & NS \\
\hline & 脳血管障害 & $3(2)$ & $0(0)$ & $1(2)$ & NS \\
\hline & 抑うつ & $27(15)$ & $9(41)$ & $5(8)$ & $\# P=0.0004$ \\
\hline
\end{tabular}

FBSS : failed back surgery syndrome, MOB : multiple operated back

\# : 手術歴あり群と手術歴なし群の間の有意差あり $(P<0.05)$.

NS : 有意差なし

月後まで有意に手術歴なし群の方が改善していた (図2).

術中に多かった合併症は頭痛・頝部痛で $37 \%$, 次いで腰下肢痛が7\%であった。術後に多かった合 併症は創部痛の $4 \%$ であり, そのほかに下肢運動障 害や膀胱直腸障害, 頭痛, 高血圧, 嘔気の訴えが
1 ～$\%$ の割合であったが，いずれも短期間のうち に消失した。重大な合併症に至った例はなかった (表3).

\section{III 考 察}

今回の調査で対象としたのは他の保存的治療に抵 

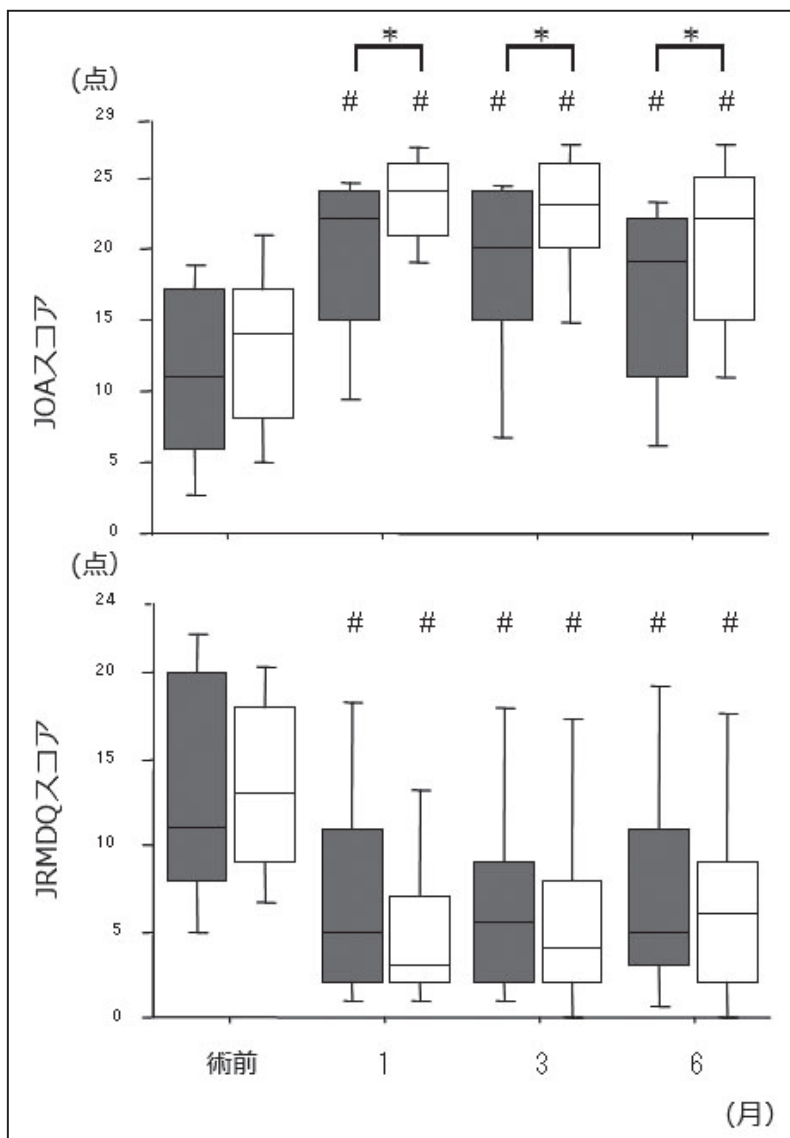

図1旧JOAスコア(上) とJRMDQスコア(下)の経時 的変化

灰色は手術歴のある群, 白色は手術歴のない群を表 わす。箱ひげ四の中の横線は中央值, 箱の下端と上 端の横線はそれぞれ 25 パーセンタイルと 75 パーセン タイルを表わし，横線はそれぞれ10パーセンタイル と90パーセンタイルを表わす。

\# : $P<0.05$ 術前と比較して有意差あり, $*: P<0.05$ 2 群間に有意差あり。

〔文献11)上り引用・改変〕

抗性の症例であるが，それでもエピドラスコピーは 一定の有効性を示した。このようにエピドラスコピ 一がある一定の難治性腰下肢痛に対して有効である ということは過去にも報告されている。最近の $3 つ$ の前向き研究 ${ }^{4) ~ 6) ~} 22$ つの後ろ向き研究 ${ }^{7)}$, , および 1つのランダム化二重盲検コントロール試験 ${ }^{9)}$ の結 果では，仙骨ブロックや腰部硬膜外ブロックで十分 な改善が得られなかった患者に対してもエピドラス コピーを行うことによって痛みと身体機能の改善が
得られることが示された ${ }^{10)}$ 。このうち Manchikanti らが2005年に報告した二重盲検試験の結果では, $70 \%$ 以上の腰椎術後患者を含む患者群を対象に癒着 剥離を行わない群と行う群に分けて評価したとこ ろ, 癒着剥離を行った群では行わなかった群に比べ て有意な改善が得られ，6力月後に $56 \% ， 1$ 年後で も $48 \%$ も症例で効果が得られていたと報告して いる ${ }^{9)}$. 海外と同様, 日本でもエピドラスコピーは 難治性の腰下肢痛患者に有効である。われわれは工 ピドラスコピー施行から 3 カ月後までの同様のデー 夕を用いて過去に有効性を報告したが ${ }^{11)}$ ，今回の結 果は6力月後にも治療効果が持続していることを示 している。これらの結果では腰椎の手術歴がある症 例群では手術歴がない群よりも有効性が劣つていた が，これは手術歴がある患者に対するエピドラスコ ピーの適応を否定するものではない。むしろ，手術 歴のある患者では有効な保存的治療の選択肢が少な いため, エピドラスコピーは有効性が期待できる数 少ない治療法の一つとして重要である.

今回のデータは 3 から 6 力月後の脱落症例が多く 有効性の評価に最適なデータではなかったが，国内 のエピドラスコピー受療患者の動態を表わしている 点では意義がある。すなわち，エピドラスコピー施 行後に $1 ， 3 ， 6$ 力後の定期的な再診予約をしてデ ー夕を収集しても，すべてが満たされるのは約半数 である，脱落症例の脱落理由は直接調査されていな いが，最終受診時の満足度およびJRMDQスコアを 解析した結果，1力月後および 3 力月後に術前より 満足度が改善していた割合はそれぞれ73\%と83\%， JRMDQスコアが改善していた割合はそれぞれ95\% と $85 \%$ と良好であった。この結果から，脱落例の 多くはエピドラスコピーの結果に満足であり, 治療 が不要になったと感じて来院しなかった例が多かっ たと推測する。また，全国のエピドラスコピー施行 施設がいまだ少ないため患者自宅から施設までの距 離が遠い傾向があることから, 腰下肢痛の症状が改 善した患者にとって術後調査に協力するために外来 
受診をするインセンティブが働かなかったことが理 解できる。

エピドラスコピーは安全性の高い治療手技であ り, 今回の結果(表3)を見ても一過性の軽微な合併 症が認められたのみであった。しかし重大な合併症 が起こる可能性は常に認識すべきである。特に内視 鏡の挿入または過量の生理食塩液注入により硬膜外 腔の圧力が限度を超えると, 脊髄圧迫や脊柱管内圧 と頭蓋内圧の上昇, 硬膜外血腫, 出血, 感染, 眼圧 上昇から下肢の麻痺や失明さえ招く可能性が指摘さ れている ${ }^{12), 13)}$ 。また，過鎮静による呼吸抑制も管理 方法が適切でないと重大な結果を招く危険性があ る。これらの重大な合併症の発生率は低いため, 上 り多くの症例で引き続き検討されるべきである。今 回の調査で手術中の頭痛・頚部痛の合併症の発生率 が手術歴のない患者群に有意に多かった理由は，硬 膜外腔の癒着の程度が比較的軽かったために生理食 塩液の注入に伴い頭蓋内圧や䅡部脊柱管内圧が上昇 しやすかったためと推測される。

今回の調査は多施設で行われたため術者が施設に より異なった。エピドラスコピーの手技は術者によ り異なる可能性があるため, 今後は特定の術者の成 績や術者間の成績の比較なども検討する余地があ る.また, 術後 6 力月以降の長期予後, さらには工 ピドラスコピーを再試行した場合の成績も検討課題 である。また，エピドラスコピーを行わない患者群 を設定して二重盲検ができない，あるいはエピドラ スコピーを希望して計画された症例を対象としたた めにエピドラスコピーを行わない群とのランダム化 ができないという研究デザイン上の制約があった。 今後は一定の症状を示す患者を対象に前向き研究を デザインすることが望ましい.

\section{まとめ}

腰椎の手術歴の有無にかかわらず，エピドラスコ ピーは難治性腰下肢痛に対して有効である。特に, 手術歴がない群では手術歴がある群と比較して有効

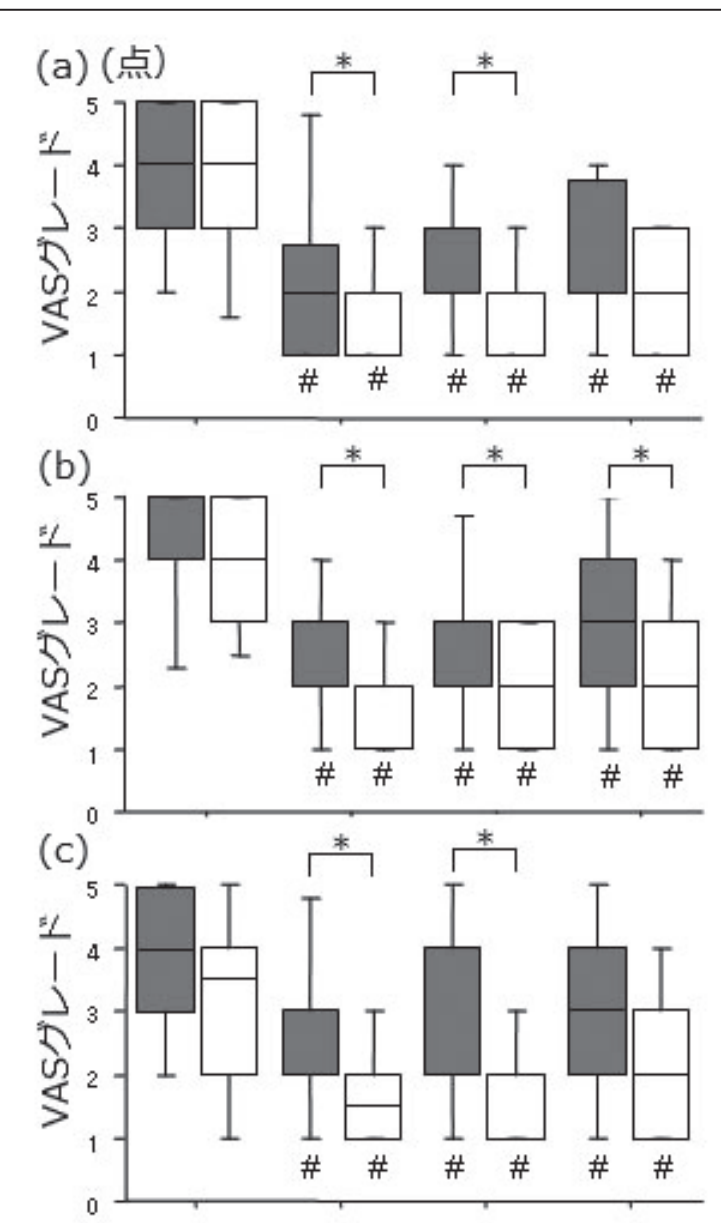

(d)

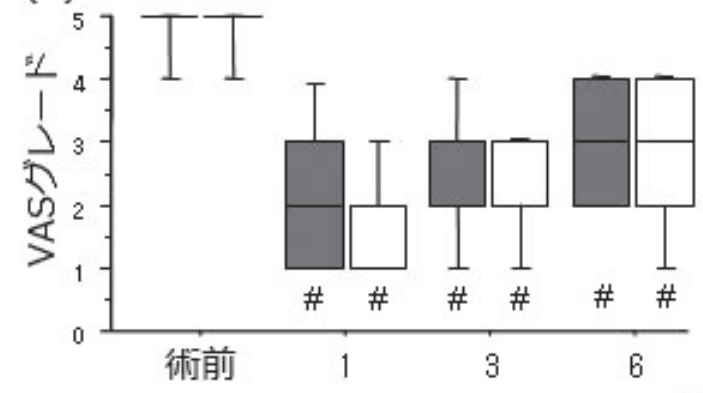

(月)

図2 VASグレード $(0 \sim 5)$ の経時的変化

灰色は手術歴のある群，白色は手術歴のない群を表 わす。 (a) 腰痛, (b)下肢痛, (c)下肢しびれ, (d) ADL 障 害を示す．箱ひげ図の中の横線は中央値，箱の下端 と上端の横線はそれぞれ 25 パーセンタイルと 75 パー センタイルを表わし，横線はそれぞれ10パーセンタ イルと 90 パーセンタイルを表わす。

\# : $P<0.05$ 術前と比較して有意差あり, $*: P<0.05$ 2 群間に有意差あり。

〔文献11)より引用・改変〕 
表3 合併症

\begin{tabular}{|c|c|c|c|c|}
\hline & \multicolumn{3}{|c|}{ 症例数 (\%) } & \multirow[b]{2}{*}{ 有意差 } \\
\hline & $\begin{array}{c}\text { 全症例 } \\
\text { (脱落症例を含む) } \\
n=180\end{array}$ & $\begin{array}{c}6 \text { 力月調査 } \\
\text { 手術歴あり } \\
n=22\end{array}$ & $\begin{array}{c}6 \text { 力月調査 } \\
\text { 手術歴なし } \\
n=62\end{array}$ & \\
\hline \multicolumn{5}{|l|}{ 術中合併症 } \\
\hline なし & $76(42)$ & $9(41)$ & $25(40)$ & NS \\
\hline 頭痛または顤部痛 & $67(37)$ & $7(32)$ & $35(56)$ & $\# P=0.047$ \\
\hline 腰下肢痛 & $13(7)$ & $4(18)$ & $1(2)$ & NS \\
\hline 下肢しびれ & $2(1)$ & $0(0)$ & $0(0)$ & NS \\
\hline 硬膜穿刺 & $6(3)$ & $1(5)$ & $1(2)$ & NS \\
\hline \multirow[t]{2}{*}{ 呼吸抑制 } & $1(1)$ & $1(5)$ & $0(0)$ & NS \\
\hline & $1(1)$ & $1(5)$ & $0(0)$ & NS \\
\hline \multicolumn{5}{|l|}{ 術後合併症 } \\
\hline なし & $159(88)$ & $20(91)$ & $61(98)$ & NS \\
\hline 創部痛 & $8(4)$ & $1(5)$ & $0(0)$ & NS \\
\hline 下肢運動障害 & $4(2)$ & $0(0)$ & $0(0)$ & NS \\
\hline 膀胱直腸障害 & $1(1)$ & $0(0)$ & $0(0)$ & NS \\
\hline 頭痛 & $3(2)$ & $1(5)$ & $0(0)$ & NS \\
\hline 高血圧 & $1(1)$ & $0(0)$ & $0(0)$ & NS \\
\hline \multirow[t]{2}{*}{ 吐気 } & $2(1)$ & $0(0)$ & $1(2)$ & NS \\
\hline & $1(1)$ & $0(0)$ & $1(2)$ & NS \\
\hline
\end{tabular}

\#: 手術歴あり群と手術歴なし群の間の有意差 $(P<0.05)$.

NS : 有意差なし

性が高かった。180例の中に重大な合併症を認めな かった。

謝辞 今回の多施設共同研究にご協力くださいまし た藤田保健衛生大学坂文種報徳會病院の河西稔先 生, 日本医科大学多摩永山病院の内木亮介先生, 防 衛医科大学校名誉教授の佐藤哲雄先生, 札幌医科大 学名誉教授の並木昭義先生, JR東京総合病院院長 の花岡一雄先生, 駿河台日本大学病院院長の小川節 郎先生をはじめエピドラスコピー研究会の会員の皆 様に感謝を申し上げます。

\section{参考文献}

1) Saberski LR, Kitahata LM : Direct visualization of the lumbosacral epidural space through the sacral hiatus. Anesth Analg $80: 839-840,1995$
2) Osawa T, Ogura T, Hayashida T, et al. : Evaluation of lumbosacral nerve root lesions using evoked potentials recorded by a surface electrode technique. Spine 28 : 496-501, 2003

3) Roland M, Morris R : A study of the natural history of back pain. Part I : development of a reliable and sensitive measure of disability in low-back pain. Spine 8 : 141-144, 1983

4) Richardson J, McGurgan P, Cheema S, et al. : Spinal endoscopy in chronic low back pain with radiculopathy. A prospective case series. Anaesthesia 56 : 454460, 2001

5) Geurts JW, Kallewaard JW, Richardson J, et al. : Targeted methylprednisolone acetate/hyaluronidase/clonidine injection after diagnostic epiduroscopy for chronic sciatica : a prospective, 1-year follow-up study. Reg Anesth Pain Med 27 : 343-352, 2002

6) Igarashi T, Hirabayashi $Y$, Seo N, et al. : Lysis of adhesions and epidural injection of steroid/local anaesthetic during epiduroscopy potentially alleviate low back and leg pain in elderly patients with lumbar spinal steno- 
sis. Br J Anaesth 93 : 181-187, 2004

7) Manchikanti L, Pampati V, Bakhit CE, et al. : Non-endoscopic and endoscopic adhesiolysis in post-lumbar laminectomy syndrome : a one-year outcome study and cost effectiveness analysis. Pain Physician $2: 52-$ 58, 1999

8) Manchikanti L : The value and safety of epidural endoscopic adhesiolysis. Am J Anesthesiol $27: 275-279$, 2000

9) Manchikanti L, Boswell MV, Rivera JJ, et al. : A randomized, controlled trial of spinal endoscopic adhesiolysis in chronic refractory low back and lower extremity pain. BMC Anesthesiol $5: 10,2005$

10) Richardson $\mathrm{J}:$ Clinical results and combined medica- tion of epiduroscopy. The Pain Clinic 19: 155-162, 2007

11) Murai K, Suzuki H, Igarashi T, et al. : Epiduroscopy for intractable low back pain or sciatica in operated and non-operated back patients : results from the Japan Society of Epiduroscopy. The Pain Clinic 19 : 163-169, 2007

12) Heavner JE, Bosscher HA : Complications of lumbosacral epiduroscopy. The Pain Clinic 19 : 179-184, 2007

13) Gill JB, Heavner JE : Visual impairment following epidural fluid injections and epiduroscopy : a review. Pain Med 6 : 367-374, 2005

\title{
Efficacy and Complications of Epiduroscopy : A Clinical Outcome of a Multi-institutional Prospective Study in Japan
}

\author{
Kunihiko MURAI*1,2, Takashi IGARASHI*1, Yui MATSUNO*1, \\ Kenji TAMAI*1, Koichi MOGI*1, Mamoru TAKEUCHI ${ }^{* 1}$ \\ ${ }^{* 1}$ Department of Anesthesiology and Critical Care Medicine, Jichi Medical University \\ ${ }^{* 2}$ Murai Orthopedic Clinic
}

A multi-institutional, prospective, clinical study was performed to investigate the efficacy and complications of epiduroscopy in patients with intractable low back and leg pain. Japanese Orthopedic Association (JOA) score (0-29, 29=best), the Japanese version of the Roland-Morris Disability Questionnaire (JRMDQ) score (0-24, 24=worst), and 100-mm visual analogue scale(VAS) for leg pain, leg numbness, low back pain and dissatisfaction with ADL were recorded before and 1, 3 and 6 months after epiduroscopy.

All scores significantly improved 1, 3 and 6 months after epiduroscopy in patients with or without history of back surgery. Patients without history of back surgery achieved significantly better improvement in JOA scores and VAS scores than those with history of back surgery. 37\% of patients reported transient headache/neck pain during epiduroscopy, $4 \%$ of patients complained of wound pain and $1-2 \%$ complained of or experienced motor disorder in the lower extremities, bladder and bowel dysfunction(BBD), headache or elevated blood pressure on a temporary basis after epiduroscopy. Neither severe nor permanent complications were observed.

Key Words : Epiduroscopy, Intractable low back and leg pain, Efficacy, Complication

The Journal of Japan Society for Clinical Anesthesia Vol.32 No.2, 2012 